\title{
Contribution of glacier melt to stream runoff: if the climatically extreme summer of 2003 had happened in 1979...
}

\author{
Gernot R. KOBOLTSCHNIG, ${ }^{1,2}$ Wolfgang SCHÖNER, ${ }^{3}$ Massimiliano ZAPPA, ${ }^{4}$ \\ Hubert HOLZMANN ${ }^{1}$ \\ ${ }^{1}$ University of Natural Resources and Applied Life Sciences (BOKU), Muthgasse 18, A-1190 Vienna, Austria \\ ${ }^{2}$ International Research Society INTERPRAEVENT, PO Box 48, A-9021 Klagenfurt, Austria \\ E-mail: gernot.koboltschnig@ktn.gv.at \\ ${ }^{3}$ Central Institute of Meteorology and Geodynamics (ZAMG), Hohewarte 38, A-1190 Vienna, Austria \\ ${ }^{4}$ Swiss Federal Institute for Forest, Snow and Landscape Research (WSL), Zürcherstrasse 111, CH-8903 Birmensdorf, \\ Switzerland
}

\begin{abstract}
This paper presents a comparative study at a small and highly glacierized catchment area in the Austrian Alps, where runoff under the extreme hot and dry conditions of summer 2003 was simulated based on two different glacier extents: the 2003 glacier extent and the $29 \%$ larger 1979 extent. Runoff was simulated applying the hydrological water balance model PREVAH at a high temporal resolution. For this purpose, the catchment area was subdivided into hydrological response units based on digital elevation model and land-cover data. The model was driven by meteorological data from the observatory at Hoher Sonnblick, situated at the highest point of the catchment area (3106 $\mathrm{m}$ a.s.l.). We were interested in the effect the change in glacier extent would have on the annual and monthly water balance and the hydrograph of hourly discharges. Results of the 2003 and the hypothetical 1979 simulation show main differences in runoff for the period July-August depending on a higher ice-melt contribution. Due to the same meteorological input, both simulations calculate the same snow accumulation and snowmelt. Annual discharge in 1979 would have been $12 \%$ higher and hourly runoff up to $35 \%$ higher than in 2003 .
\end{abstract}

\section{INTRODUCTION}

Glaciers can regulate and compensate the water supply of alpine catchments during warm, dry summer periods. The fraction of ice melt during summer strongly depends on the glacierized share of the catchment area, the area and the time period at which bare ice is exposed to solar radiation and the climatic conditions at the catchment. The summer of 2003 in Europe was an outstanding event (Beniston, 2004; Schär and others, 2004). Analysis of the long-term climatological time series of Sonnblick observatory, Austria, from 1886 until the present (Auer and others, 2002) shows that the mean summer (June-August) air temperature was exceeded by $3.9^{\circ} \mathrm{C}$ in 2003 . The mean summer air temperature for the period $1961-90$ was exceeded by $3.7^{\circ} \mathrm{C}$ in 2003 (see Table 1). The hot and dry conditions in summer 2003 had an extreme impact on glacier melt, so that the 2002/03 annual glacier net balance of Goldbergkees, Austria, was the most negative since the start of observations (Hynek and Schöner, 2004; Schöner and others, 2004). Table 1 shows that in 2003 June and August were exceptionally warm and dry compared to the long-term mean values (climate normal period 1961-90; Auer and others, 2002), but, comparing the annual precipitation and air temperatures, no extreme anomalies can be seen for 2003. It should be noted that $60 \%$ of the August precipitation was registered in the last 3 days of the month, and only then did slightly negative air temperatures appear.

Runoff observations during summer 2003 show distinctive diurnal variations induced by ice melt and high peak discharges during periods without rainfall (Fig. 3a and b, further below). Collins (2005) gives an overview of the temporal variations of climate change and runoff. It is mentioned that most of the Alpine glaciers declining from their extension during the Little Ice Age contributed their maximum ice melt at about the beginning of the 20th century. Hence, although an extreme summer was observed in 2003 and more extreme summers may follow, the reduced glacier extents will not allow more extreme icemelt contributions. In this paper, we present a study in which the hydrological response of a glacierized basin under the extreme climate conditions of 2003 is simulated using the past glacier extent of 1979 compared to the reaction of the present glacier extent. The results show a nonproportional reaction of the ice-melt contribution against the changed glacier extent. The 1979 glacier extent was used due to data availability (maps and digital elevation model (DEM)) and a major difference in the glacier surfaces. Similar studies present the impact assessment at glacierized basins due to a possible climate change in future, driven by

Table 1. Mean air temperature and cumulative precipitation at Sonnblick observatory (3106 ma.s.I.): comparison of the 2003 and the long-term (1960-90) values

\begin{tabular}{lcccc}
\hline & $\begin{array}{c}T_{1961-90} \\
{ }^{\circ} \mathrm{C}\end{array}$ & $\begin{array}{c}T_{2003} \\
{ }^{\circ} \mathrm{C}\end{array}$ & $\begin{array}{c}P_{1961-90} \\
\mathrm{~mm}\end{array}$ & $\begin{array}{c}P_{2003} \\
\end{array}$ \\
& & & & $\mathrm{~mm}$ \\
\hline June & -0.6 & +4.6 & 250 & 172 \\
July & +1.8 & +3.3 & 249 & 232 \\
August & +1.8 & +5.9 & 230 & 144 \\
June-August & +1.0 & +4.7 & 729 & 548 \\
Annual & -5.7 & -4.4 & 2680 & 2810 \\
\end{tabular}




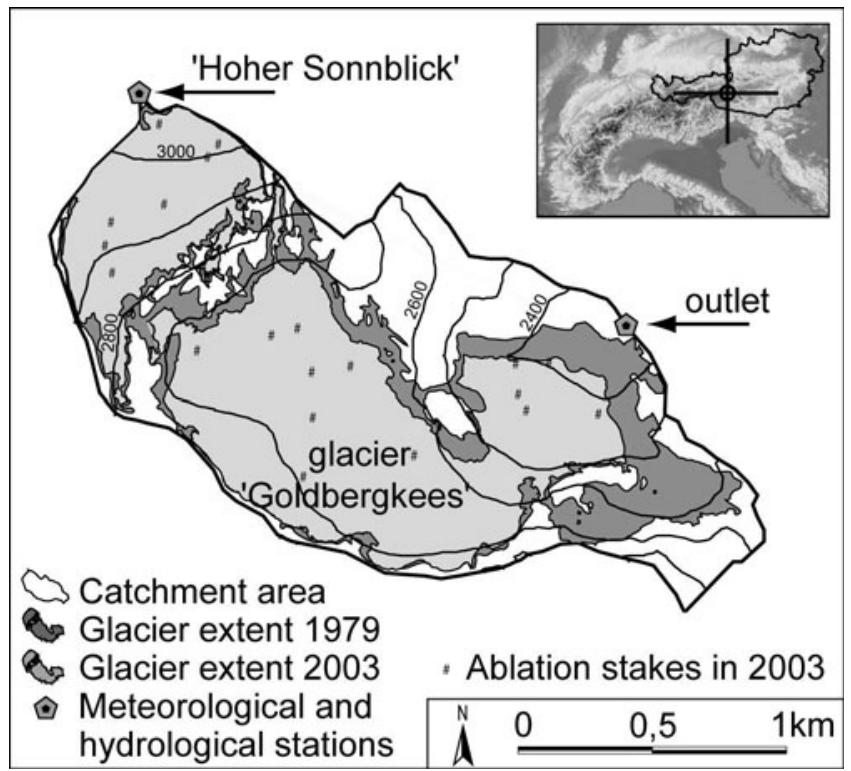

Fig. 1. Location of the Goldbergkees basin. The catchment area is outlined by the black solid line, with $100 \mathrm{~m}$ contour lines, hydrometeorological stations and change of the glacier extent (light grey: 2003; dark grey: 1979). Black dots indicate the distribution of the 20 ablation stakes drilled into the ice in the 2003 melt season.

the doubling of $\mathrm{CO}_{2}$ (Singh and Kumar, 1997; Braun and others, 2000; Rees and Collins, 2006). In this paper, we work out a comparison in order to understand the past.

\section{STUDY AREA}

The catchment area of Goldbergkees is situated directly beneath the Hoher Sonnblick observatory (3106 ma.s.l.; $47^{\circ} 03^{\prime} 16^{\prime \prime} \mathrm{N}, 12^{\circ} 57^{\prime} 25^{\prime \prime} \mathrm{E}$ ) in the Austrian Alps (Figs 1 and 2). Meteorological observations at the observatory have been conducted since 1886; mass-balance measurements at nearby glaciers started in 1983 (Auer and others, 2002). Some hydrological investigations have been carried out since 2002 (Koboltschnig and others, unpublished data). The main advantage of this study area for hydrological investigations is the availability of long-term observations of meteorological and glaciological data. The Goldbergkees
Table 2. Absolute and relative area ratio of $100 \mathrm{~m}$ elevation bands of the glacier extent in 1979 and 2003, assigned to the catchment area of $2.72 \mathrm{~km}^{2}$

\begin{tabular}{lrrrr}
\hline Elevation band & \multicolumn{2}{c}{ Glacier cover 2003 } & \multicolumn{2}{c}{ Glacier cover 1979 } \\
$\mathrm{m}$ & $\%$ & $\mathrm{~km}^{2}$ & $\%$ & $\mathrm{~km}^{2}$ \\
\hline $2300-2400$ & 0.5 & 0.01 & 3.1 & 0.08 \\
$2400-2500$ & 6.5 & 0.18 & 8.8 & 0.24 \\
$2500-2600$ & 1.7 & 0.05 & 5.6 & 0.15 \\
$2600-2700$ & 23.8 & 0.64 & 28.8 & 0.78 \\
$2700-2800$ & 6.2 & 0.17 & 9.4 & 0.26 \\
$2800-2900$ & 4.1 & 0.11 & 5.4 & 0.15 \\
$2900-3000$ & 7.4 & 0.20 & 7.7 & 0.21 \\
$3000-3100$ & 2.2 & 0.06 & 2.3 & 0.06 \\
Total & 52.3 & 1.42 & 71.1 & 1.93 \\
& & & & \\
\hline
\end{tabular}

watershed area is about $2.72 \mathrm{~km}^{2}$. Elevations range between 2350 (outlet) and $3106 \mathrm{ma.s.l}$. (observatory at Hoher Sonnblick). In 2003 about $1.42 \mathrm{~km}^{2}$ (52\% of the area) and in 1979 about $1.93 \mathrm{~km}^{2}$ (71\%) were glacierized. The main difference, due to glacier-surface changes from 1979 to 2003, can be seen in Table 2. In 1979 even the lower and middle elevation bands were covered by a wider glacier surface. The three uppermost elevation bands show nearly the same glaciation in 1979 as in 2003.

No part of the catchment is lower than the timberline. The dominant land cover is rock (central alpine gneiss), gravel and ice. The mean air temperature at Sonnblick observatory is about $-5.7^{\circ} \mathrm{C}$, and annual precipitation averages about $2680 \mathrm{~mm}$ (climate normals 1961-90; Auer and others, 2002). The retreat of the glacierized area from 1980 to 2005 can be seen in Figure 2.

\section{METHODS}

\section{Meteorological network and field investigations}

As a major input to the hydrological model, hourly data of precipitation $(\mathrm{mm})$, air temperature $\left({ }^{\circ} \mathrm{C}\right)$, relative humidity $(\%)$, wind speed $\left(\mathrm{m} \mathrm{s}^{-1}\right)$, sunshine duration (value $\left.0-1\right)$ and global radiation $\left(\mathrm{W} \mathrm{m}^{-2}\right)$ were taken from the observatory at the top of Hoher Sonnblick (Fig. 1). Air-temperature and
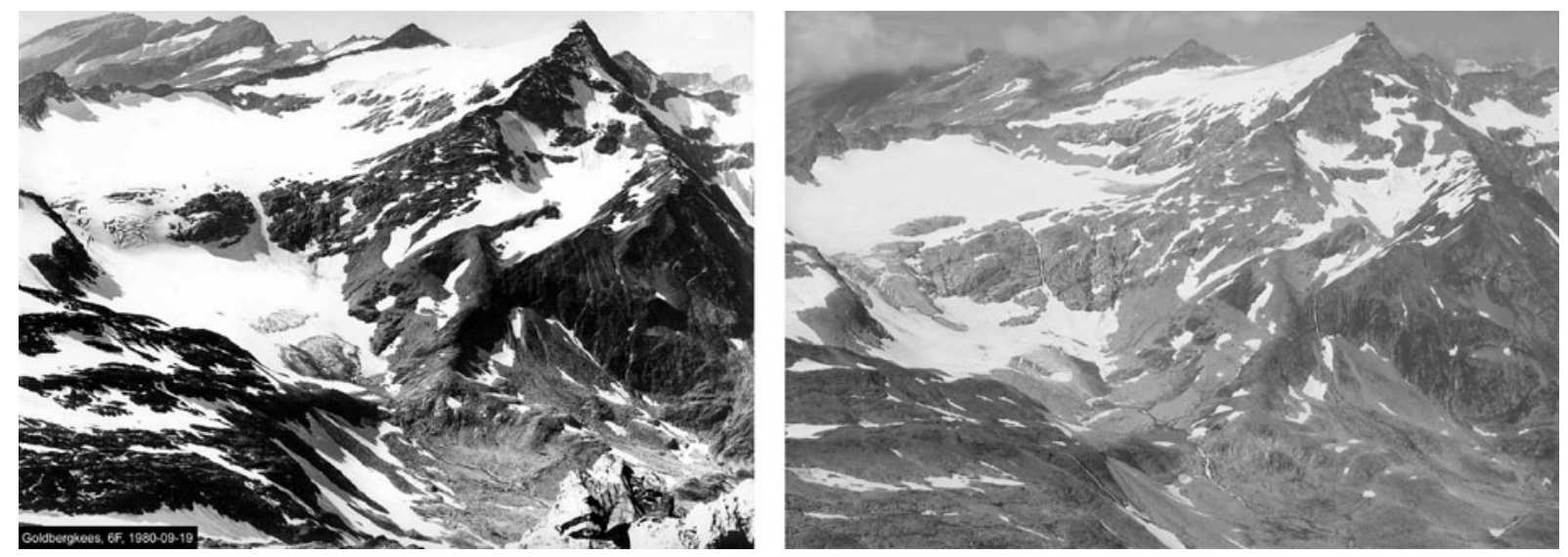

Fig. 2. Photographs of Goldbergkees from a neighbouring mountain. Left image: 19 September 1980; right image: 28 July 2005. At the highest point on the right of the pictures, the observatory, and downstream of the glacier tongue the proglacial lake at the catchment outlet, can be seen. Photographs by R. Böhm (left) and G. R. Koboltschnig (right). 

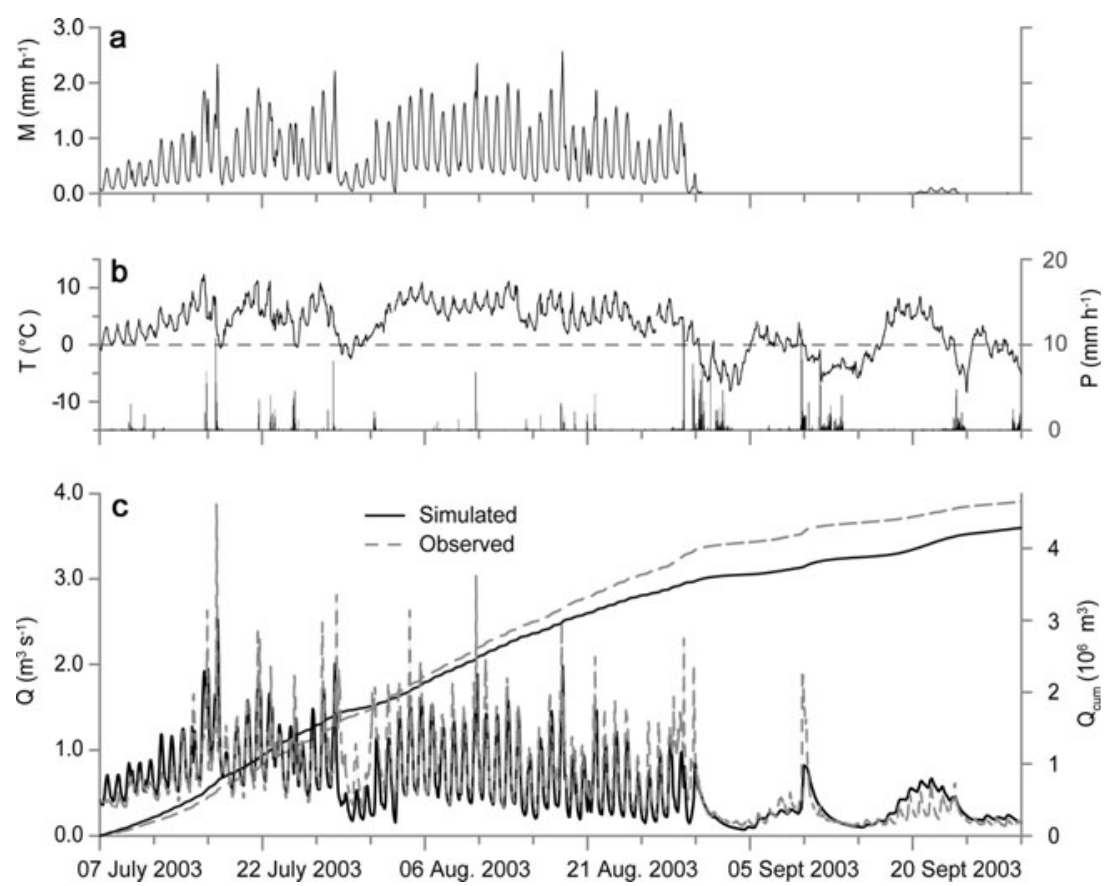

Fig. 3. (a) Simulated ice melt $M\left(\mathrm{~mm} \mathrm{~h}^{-1}\right)$ averaged over the catchment area; (b) hourly data of air temperature $T\left({ }^{\circ} \mathrm{C}\right)$ and precipitation $P$ $\left(\mathrm{mm} \mathrm{h}^{-1}\right)$ at Hoher Sonnblick observatory; and (c) observed and simulated discharge $Q\left(\mathrm{~m}^{3} \mathrm{~s}^{-1}\right)$ at the catchment outlet of Goldbergkees. The rising curves in (c) indicate the cumulative discharge $Q_{\text {cum }}\left(10^{6} \mathrm{~m}^{3}\right)$ over the period of discharge observations, 7 July-30 September 2003.

precipitation data collected at the observatory in 2003 are shown in Figure 3b. Water levels were recorded between July and October at a natural cross-section of a lake outlet at about $250 \mathrm{~m}$ downstream of the glacier tongue (Figs 1 and 2). Discharge was measured at different water levels, using propeller measurements for higher, and salt dilution gauging for lower $\left(<0.5 \mathrm{~m}^{3} \mathrm{~s}^{-1}\right)$, discharges to obtain the rating curve for runoff calculations. The estimated error for the discharge calculation, including the errors for the velocity measurements and water-level observations, is $8 \%$.

The ice ablation was measured as a standard programme of the mass-balance measurements following the glaciological method (Kaser and others, 2003) using ablation stakes drilled into the bare ice of the glacier. The net ablation of the glacier was calculated using 20 ablation stakes (see Fig. 1) distributed over the entire ablation area of Goldbergkees (Hynek and Schöner, 2004). The results of the mass-balance measurements are used to validate the simulated ice melt. The maximum snow-free extent of the glacier at the end of the ablation period in 2003 was mapped using the global positioning system (GPS).

\section{The hydrological model PREVAH}

The spatially distributed hydrological model PREVAH (precipitation-runoff-evapotranspiration-HRU (hydrological response unit) model; Gurtz and others, 1999) was used to simulate the processes contributing to runoff. PREVAH has already been used at glacierized sites at different spatial resolution (Badoux, 1999; Zappa and others, 2000, 2003; Gurtz and others, 2003). The catchment area is subdivided into HRUs based on DEM and land-cover data. For every $H R U$ the hydrological response to the meteorological input is simulated, using a conceptual storage cascade (Bergström, 1976). The runoff contributions of all HRUs are added to calculate the total runoff at the outlet of the entire catchment. The main advantage of the HRU concept is that it reduces the simulation time. In this study, the radiationbased temperature-index approach after Hock (1999) is applied to model ice- and snowmelt:

$$
M= \begin{cases}\frac{1}{n}\left(\mathrm{MF}_{\text {snow } / \text { ice }}+a_{\text {snow } / \text { ice }} I\right) T & T>0 \\ 0 & T \leq 0\end{cases}
$$

where $M$ is the calculated melt rate $\left(\mathrm{mm} \mathrm{h}^{-1}\right), \mathrm{MF}_{\text {snow/ice }}$ is the melt factor for snow or ice $\left(\mathrm{mm} \mathrm{d}^{-1} \mathrm{~K}^{-1}\right), a_{\text {snow/ice }}$ is the radiation melt factor for snow or ice, $l$ is the potential clearsky direct solar radiation at the ice or snow surface $\left(\mathrm{W} \mathrm{m}^{-2}\right)$, $T$ is the air temperature $\left({ }^{\circ} \mathrm{C}\right)$ and $n$ is the number of timesteps per day, in this case 24 hours. The melt factors for snow and ice are empirical coefficients and $I$ is a calculated value following Hock (1999). The melt factor for snow $\left(\mathrm{MF}_{\text {snow }}\right)$ is implemented as variable in time applying a sinus-shaped curve with the maximum at 21 June and the minimum at 21 December. The temperature-dependent melt factor for ice $\left(\mathrm{MF}_{\text {ice }}\right)$ is constant in time. Only air temperature is needed as input to the model; radiation is calculated as the site-adjusted potential direct radiation for each HRU, considering exposition and slope (Hock, 1999). To calculate snow accumulation, surface runoff and evaporation, PRE$\mathrm{VAH}$ additionally requires precipitation, water-vapour pressure, global radiation, wind speed and sunshine duration as input.

\section{Model application at Goldbergkees}

In a previous study (Koboltschnig and others, unpublished data), PREVAH was calibrated applying a multi-validation approach using the input data of the hydrological year 2005 in the Goldbergkees catchment area. The calibrated parameters were used for all the following simulations: threshold temperature for snowmelt $=0^{\circ} \mathrm{C}$; maximum degree-day factor $=3.2 \mathrm{~mm} \mathrm{~d}^{-1} \mathrm{~K}^{-1}$; minimum degree-day factor $=1 \mathrm{~mm} \mathrm{~d}^{-1} \mathrm{~K}^{-1}$; radiation melt factor for snow = $0.00015 \mathrm{~mm} \mathrm{~W}^{-1} \mathrm{~m}^{2} \mathrm{~K}^{-1} \mathrm{~h}^{-1}$; temperature melt factor for 


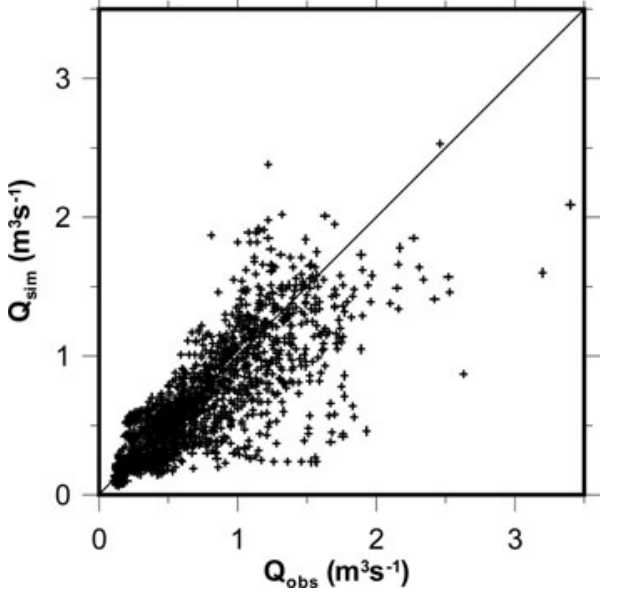

Fig. 4. Scatter plot of observed vs simulated discharges over the period of discharge observations, 7 July-30 September 2003.

ice $=2.15 \mathrm{~mm} \mathrm{~d}^{-1} \mathrm{~K}^{-1}$; radiation melt factor for ice $=$ $0.0003 \mathrm{~mm} \mathrm{~W}^{-1} \mathrm{~m}^{2} \mathrm{~K}^{-1} \mathrm{~h}^{-1}$; storage time for snowmelt $=$ 25 hours; storage time for ice melt $=2$ hours; translation time for snowmelt $=3$ hours; translation time for ice melt $=2$ hours. The hydrological year 2002/03 was modelled using DEM data of 1998 (Auer and others, 2002) and the glacier extent computed from aerial photographs taken in September 2003. The simulation of the hypothetical hydrological year 1978/79 was applied using the 1979 DEM and glacier extent, digitized from an aerial photograph. The 1998 DEM was produced applying photogrammetric methods, and the 1979 DEM was an adaptation of the 1998 DEM by digitizing the contour lines covering the glacier using a paper map from 1979.

HRUs were separated using two land-cover classes (glacier and rock), $50 \mathrm{~m}$ elevation bands (16 classes), nine aspect classes and six slope classes. HRUs were generated separately for 1979 and 2003, because the change of the DEM and the different glacier extent affected the amount and combination of HRUs. Thus, 722 HRUs and 197 meteorological units (MU) were generated for 2003, and $850 \mathrm{HRUs}$ and $231 \mathrm{MU}$ for 1979. MU are the spatial units covering the watershed for which the meteorological data have been interpolated based on hourly data from the Sonnblick observatory. A lapse rate of $0.65 \mathrm{~K}(100 \mathrm{~m})^{-1}$, calculated from long-term observations, was applied for the air-temperature regionalization. Two stations, one inside and one next to the catchment area measuring monthly precipitation sums, were used for a better weighting for the inverse distance weighting (IDW) interpolation of precipitation. The meteorological input for the 1979 simulation was the same as for the simulation of the hydrological year 2003. For both simulations runs, the model was initialized on 1 October, calculating the snow accumulation during winter and finally simulating snow- and ice-melt processes during the ablation period until 30 September.

\section{RESULTS AND DISCUSSION}

The comparison of observed and simulated runoff data during the period 7 July-30 September 2003 is shown in Figure $3 \mathrm{c}$ and in the scatter plot in Figure 4. The model performance for the period of observed runoffs was calculated as $R^{2}=0.65$ following the criterion of Nash and
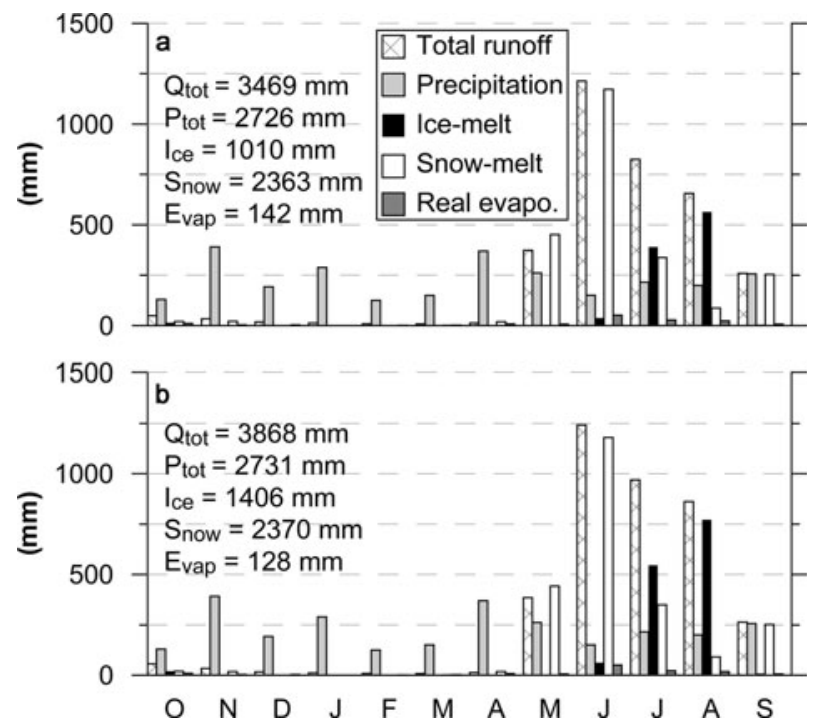

Fig. 5. Water balance of Goldbergkees catchment using meteorological input data of 2003 simulated for the glacier extent of (a) 2003 and (b) 1979. Q $Q_{\text {tot }}$ is the total annual runoff, $P_{\text {tot }}$ is the annual areal precipitation, $I_{\text {ce }}$ is the annual ice melt, $S_{\text {now }}$ is the annual snowmelt and $E_{\text {vap }}$ is the annual evaporation.

Sutcliffe (1970). Simulated discharge has a slight tendency to underestimate the observations which can be seen at the curves of the cumulated discharges (Fig. 3c). The scatter plot (Fig. 4) shows the same, and that the highest observations have not been simulated as high. We assume that the main underestimations of the modelled discharges are due to missing or too low precipitation signals, i.e. precipitation not caught by the gauging system. Simulated distinct diurnal variations of the ice melt, which are the result of airtemperature and radiation variations, are shown in Figure 3a. Due to nearly snow-free conditions in August 2003, the melting of the exposed bare ice was the major fraction of runoff. Approximately $86 \%$ of the total runoff in August 2003 originated from ice melt (Fig. 5a). In July 2003, ice melt contributed about $47 \%$ of the monthly total runoff. For the entire modelling period 2002/03, PREVAH calculated an ice loss of $-1830 \mathrm{~mm}$ assigned to the glacier surface of 2003 . This result is comparable to the observed specific glacier mass balance of Goldbergkees, which had its minimum during the range of observations in the hydrological year 2002/03 at $-1806 \mathrm{~mm}$ (Hynek and Schöner, 2004). The ice loss of the entire 2002/03 period was calculated as 29\% of the total runoff. The annual snowmelt was calculated as $68 \%$ of the total runoff.

The simulation of the hypothetical hydrological year 1978/79 (glacier extent of 1979, using the meteorological input of 2003) has a similar hydrograph during the period before the fraction of ice melt increases. In Figure 6 it can be seen that the simulations of the glacier extent in 2003 and 1979 show the same hydrograph in the period from 1 June to approximately mid-June. As soon as the ice-melt fraction increases, the diurnal maximum discharges in 1979 exceed the maxima in 2003. The highest deviation of simulated hourly discharges was calculated at $1700 \mathrm{~h}$ on 18 August as $+0.68 \mathrm{~m}^{3} \mathrm{~s}^{-1}$ at a peak discharge of $1.98 \mathrm{~m}^{3} \mathrm{~s}^{-1}$ simulated for 2003 (see Fig. 6). The mean deviation of the hourly discharge between the 1979 and 2003 simulations during the period 1 June-31 August (same period as shown in Fig. 6) 


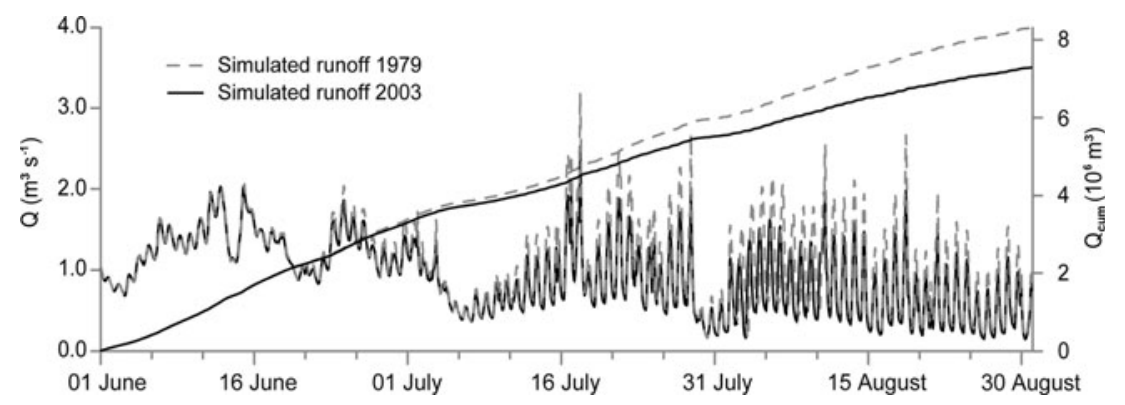

Fig. 6. Simulated 1979 runoff (dashed line) vs simulated 2003 runoff (solid line). The rising curves indicate the cumulative discharge $Q_{\text {cum }}$ $\left(10^{6} \mathrm{~m}^{3}\right)$ over the period 1 June-30 August.

is $+0.13 \mathrm{~m}^{3} \mathrm{~s}^{-1}$; for the period 1 July-31 August the deviation is $+0.18 \mathrm{~m}^{3} \mathrm{~s}^{-1}$. Another comparable feature is the mean deviation of the daily minimum discharges, which was calculated as $+0.06 \mathrm{~m}^{3} \mathrm{~s}^{-1}$ in 1979 for the period 1 July31 August. The deviation of the cumulative discharge in the period 1 June-31 August of 2003 and 1979 accounts for about $1.03 \times 10^{6} \mathrm{~m}^{3}$. This is a difference of about $14 \%$, due to the higher glacier extent in 1979. The difference in total runoff is $12 \%$ calculated for the entire hydrological year starting in October 2002 or October 1978. Comparing the plot of monthly cumulated discharge, precipitation, ice melt, snowmelt and evaporation of 1979 and 2003 (see Fig. 5a and b), the main change appears only in July and August, when only ice melt and total runoff show larger differences. Ice melt is the driving factor for changes in total runoff. In July and August $1979,40 \%$ and $37 \%$ more ice melt, respectively, contributed to runoff compared to 2003. In August 1979, $89 \%$ of the total runoff was ice melt. The annual ice melt was calculated as $36 \%$ of the total runoff, which is about $1980 \mathrm{~mm}$, assigned to the glacierized area of 1979 . The annual snowmelt was calculated as $61 \%$ of the total runoff.

\section{CONCLUSION}

The application of PREVAH to the glacierized catchment area of Goldbergkees shows an acceptable model performance of $R^{2}=0.65$ for the simulation of the summer 2003 melt period, following the criterion of Nash and Sutcliffe (1970). Model results show that about $86 \%$ of the total runoff in August 2003 was ice melt, due to nearly snow-free conditions. The surface of Goldbergkees in 1979 was about $129 \%$ of the 2003 surface. Simulation results for the hypothetical $1978 / 79$ period show a $12 \%$ higher total annual runoff compared to the 2002/03 period, due to the higher fraction of the basin surface that was ice-covered. In summer 2003 the ice melt of a 52\% glacierized surface, and in 1979 the ice melt of a $71 \%$ glacierized surface, contributed to total runoff because of nearly snow-free conditions. The change in the glacier's topography, with much of the glacierized surface at lower elevations disappearing during the 24 year interval 1979-2003 (see Table 2; Fig. 1, next to the catchment outlet), resulted in total ice-melt rates in July and August 2003 that were up to 29\% lower than in 1979. This is due to the results of the simulated specific glacier mass balance which accounts for $1830 \mathrm{~mm}$ in 2003 and about $1980 \mathrm{~mm}$ in 1979 (using the 2003 meteorological input).

A bigger difference between the two compared specific mass balances would only be possible if the glacierized area fraction at lower elevations were higher. Hence, if the impact of an extremely warm summer like 2003 had appeared in 1979, it would have resulted in much higher discharges driven by glacial melt. For possible future scenarios, assuming smaller glacier surfaces, this means that, to produce more extreme ice-melt contributions, warmer conditions or as warm conditions but with longer durations compared to summer 2003 are necessary. To compare the hourly runoff, we calculated key values showing the deviation from 1979 to 2003. The maximum deviation appeared at the peak discharge on 18 August and was calculated as $+34 \%$, and the mean deviation of hourly discharges for the period 1 July-31 August was calculated as $+24 \%$. The maximum deviation was the result of a melt event, which was superposed by a rainfall event. Furthermore the mean daily minimum runoff in the period 1 July31 August was 14\% higher in 1979 than in 2003.

Summarizing, we can state that the comparison of the simulation of the extreme summer 2003 and the hypothetical summer 1979 using PREVAH has shown a wide range of analyzable results, but primarily that knowledge of the spatial topography, mainly the area ratio of the different elevation bands of glacierized areas, is needed to estimate the ice-melt contribution of different glacier extents.

\section{ACKNOWLEDGEMENTS}

This ongoing research is supported by a grant from the Austrian Academy of Sciences under the project SNOWTRANS HOE29, part of the IHP PUB (International Hydrological Program, Prediction in Ungauged Basins). The authors are grateful to all the students, colleagues and friends who helped to carry out the exhausting fieldwork. Meteorological time series were provided by ZAMG. We thank R. Hodkins for his scientific editorial work. D.A. Swift and an anonymous reviewer made valuable remarks and suggestions.

\section{REFERENCES}

Auer, I., R. Böhm, M. Leymüller and W. Schöner. 2002. Das Klima des Sonnblicks: Klimaatlas und Klimatographie der GAWStation Sonnblick einschließlich der umgebenden Gebirgsregion. Österreich. Beitr. Meteorol. Geophys., 28.

Badoux, A. 1999. Untersuchung zur flächendifferenzierten Modellierung von Abfluss und Schmelze in teilvergletscherten Einzugsgebieten. (Diploma thesis, ETH Zürich.)

Beniston, M. 2004. The 2003 heat wave in Europe: a shape of things to come? An analysis based on Swiss climatological data and model simulations. Geophys. Res. Lett., 31(2), L02202. (10.1029/2003GL018857.) 
Bergström, S. 1976. Development and application of a conceptual runoff model for Scandinavian catchments. Lund, University of Lund. Lund Institute of Technology. (Bull. Ser. A, No. 52.)

Braun, L.N., M. Weber and M. Schulz. 2000. Consequences of climate change for runoff from Alpine regions. Ann. Glaciol., 31, 19-25.

Collins, D.N. 2005. Climatic variation and runoff in mountain basins with differing proportions of glacier cover. In SemadeniDavies, A., L. Bengtsson and G. Westerström, eds. Proceedings of the 15th Northern Research Basins International Symposium and Workshop, 29 August-2 September 2005, Luleå to Kvikkjokk, Sweden. Lund, University of Lund, 21-30.

Gurtz, J., A. Baltensweiler and H. Lang. 1999. Spatially distributed hydrotope-based modelling of evapotranspiration and runoff in mountainous basins. Hydrol. Process., 13(17), 2751-2768.

Gurtz, J. and 6 others. 2003. A comparative study in modelling runoff and its components in two mountainous catchments. Hydrol. Process., 17(2), 297-311.

Hock, R. 1999. A distributed temperature-index ice- and snowmelt model including potential direct solar radiation. J. Glaciol., 45(149), 101-111.

Hynek, B. and Schöner, W. 2004. Massenhaushalt 2002/2003 der Gletscher in der Goldberggruppe. Jahrb. Sonnblick-Ver., 101102, 1-15.

Kaser, G., A. Fountain and P. Jansson. 2003. A manual for monitoring the mass balance of mountain glaciers. Paris, UNESCO. International Hydrological Programme. (IHP-VI Technical Documents in Hydrology 59.)
Nash, J.E. and J.V. Sutcliffe. 1970. River flow forecasting through conceptual models. Part 1. A discussion of principles. J. Hydrol., 10(3), 282-290.

Schar, C. and 6 others. 2004. The role of increasing temperature variability in European summer heatwaves. Nature, 427(6972), $332-336$.

Rees, H.G. and D.N. Collins. 2006. Regional differences in response of flow in glacier-fed Himalayan rivers to climatic warming. Hydrol. Process., 20(10), 2157-2169.

Schöner, W., I. Auer, R. Böhm, B. Hynek, H. Holzmann and G. Koboltschnig. 2004. Extreme glacier melt in Hohe Tauern region (Austrian Alps). In Herrmann, A., ed. International Conference on Hydrology of Mountain Environments, 27 September-1 October 2004, Berchtesgaden, Deutschland; Landschaftsökologie und Umweltforschung, Extended Abstracts, 47. Braunschweig, Universität Braunschweig. Selbstverlag Institut für Geoökologie, 319-322.

Singh, P. and N. Kumar. 1997. Impact assessment of climate change on the hydrological response of a snow and glacier melt runoff dominated Himalayan river. J. Hydrol., 193(1-4), 316-350.

Zappa, M., A. Badoux and J. Gurtz. 2000. The application of a complex distributed hydrological model in a highly glaciated alpine river catchment. Int. Assoc. Danube Res., Limnol. Rep., 33, 23-28.

Zappa, M., F. Pos, U. Strasser, P. Warmerdam and J. Gurtz. 2003. Seasonal water balance of an alpine catchment as evaluated by different methods for spatially distributed snow melt modelling. Nord. Hydrol., 34(3), 179-202. 